\title{
P-359泌尿器科領域における術後憼染の模討
}

健康保険諫早総合病院泌尿器科、公立みつぎ総合病院泌尿科

白石和孝、垣本 滋前川直文、古川正隆

【目的】過去 3 年間に施行した手術症例474例について血液、生化学值の変動、尿所見、尿量、堅機能等 を測定し、術後使用抗生剤、手術術式等と比較し、術後尿路感染との関係について検討した。【対象なら

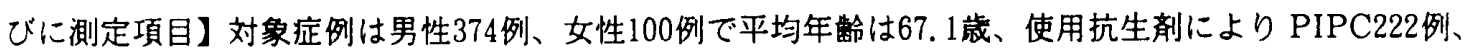
CMNX167例、FOM39例、その他46例の 4 群に分類した。いずれも単剂使用例で使用量は原則として術


術前、術後にPSP值、Ccr值を測定した。手術術式はTUR - P 173例、TUR - Bt132例TUR-P・Bt 11 例 堅摘出術34例、尿道の手術36例、膀胱碎石術18例、尿管切石術26例、その他44例である。【結果】使用抗 生棛による尿路感染の差は認められなかった。手術時間、麻酔時間との関係では術後の尿蛋白との間に手 術時間は明らかに相関が認められたが、細菌尿、膿尿之の関係は認められなかった。手術術式による差で は、TUR－P、TUR－Bt症例は明らかに他の手術例に比し細菌尿、朖尿は強く認められた。ただ抗生剂 の增量を必要とする程強くはなかった。下部尿路手術でも、梳胱碎石術、尿道の手術では尿路感染症はほ とんど認められず、カラーテル留置期間との関係も認められなかった。今回対象とした症例は高路ではあっ たか、術前堅機能は Ccr で平均 $69.6 \mathrm{m \ell} / \mathrm{min}$ と比較的良好であり、術後 1 日目の尿量も平均 $2536.0 \mathrm{ml}$ 十分に得られたためか、尿路感染は軽度であり、術後 1 日目の白血球の上昇も平均 $8513 / \mathrm{mm}$ 亡わずかであっ た。【結語】下部尿路手術、特にTUR 症例において術後尿路感染は避けられないが、十分な利尿をつけ る事によりある程度軽減する可能性が示唆された。

\section{P-360尿中分離MR S A の隐床的换时}

鳥取计立病院泌尿器科

白䗁義範、早田俊司

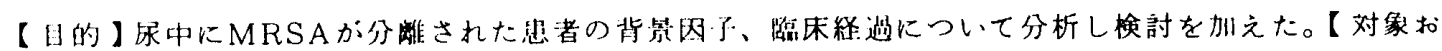

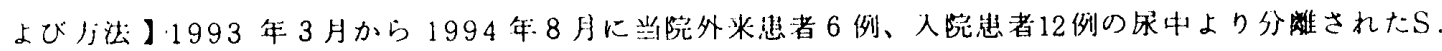
aureus18株を対象とした。MRSAの判定は1濃度ディスク法によりoxacillinおよびCefazolinに刘


る膀胱洗浄を行い評価した。【結果】(1)外来分離 6 例中 2 例、入院分離12例中10例か MRSAであった。 (2)カテーテル留置例はMSSA分離 6 例中 3 例 (50\%)、MRSA分崔12例中 8 例 $(66.7 \%$ ) と後者に多 <、抗菌剤投与例（分離前10日間）。MSSA分離 6 例中 1 例 (16.7\%)、MRSA分離12例中 6 例( 50 $\%$ ）と後者に多く見ら九た。(3)有熱例（ $38^{\circ} \mathrm{C}$ 以上）は、MSSA離 6 例中 2 例、MRSA分㠛 12 例中 2 例 であった。(4)MRSAに対する抗菌剤の感受性：MINO,ABK,VCMKは耐性株は見られなかった。(5) MRSA 分離例の臨床経過：有熱 2 例はともに抗菌剂投与により解熱し、MRSA む消失した。非有熱 10 例では、5 例に抗菌阂を投与し、全例でMRSAの消失を認めた。インシン膀胱洗浄 4 例中1例にMRSA の消失を見た。【考察】カテーテル留置怙よび抗菌郕の投与とMRSA出現とは密接な関係があると考え

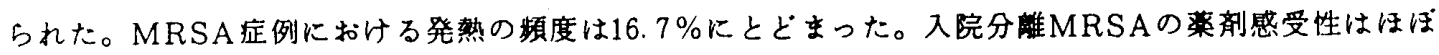
同一ハターンで院内感染が示唆された。 